\title{
Mini-implants: Mechanical resource for molars uprighting
}

Susiane Allgayer ${ }^{1}$, Deborah Platcheck², Ivana Ardenghi Vargas³, Raphael Carlos Drumond Loro ${ }^{4}$

Introduction: The early orthodontic treatment allows correction of skeletal discrepancies by growth control, and the elimination of deleterious habits, which are risk factors for the development of malocclusions, favoring for the correction of tooth positioning later in a second treatment stage. During development of teeth and occlusion, the mandibular second molars commonly erupt in the oral cavity after all other teeth of the anterior region. In their eruptive process there may be a condition known as tooth impaction, which precludes its complete eruption and requires proper uprighting treatment. The temporary anchorage devices allow disimpaction and movement of these teeth directly to their final position, without the need of patient compliance or reaction movements in other parts of the arch. Objective: This paper aims at describing a case report of the treatment of a patient with Angle Class II malocclusion, performed in two phases, in which mini-implants were used for uprighting the impacted mandibular second molars.

Keywords: Corrective orthodontics. Orthodontic anchorage procedures. Impacted tooth.

Introdução: o tratamento ortodôntico precoce permite a correção das discrepâncias esqueléticas por meio do controle de crescimento e a eliminação de hábitos deletérios, que são fatores de risco para o desenvolvimento de más oclusões, que favorecem a correção do posicionamento dentário mais tardiamente, em uma segunda fase do tratamento. Durante o desenvolvimento da dentição e da oclusão, normalmente o segundo molar inferior chega à cavidade bucal após todos os dentes posicionados anteriormente a ele. Durante seu processo eruptivo, pode ocorrer uma condição chamada "impacção dentária”, em que sua erupção completa é interrompida, exigindo tratamento apropriado para verticalização. Os dispositivos temporários de ancoragem permitem a desimpacção e a movimentação desses dentes diretamente às suas posições finais, sem a necessidade de cooperação do paciente e sem movimento de reação nas outras unidades da arcada. Objetivo: descrever o tratamento de um caso de má oclusão Classe II de Angle, realizado em duas fases, durante o qual foram utilizados mini-implantes para verticalização dos segundos molares inferiores impactados.

Palavras-chave: Ortodontia corretiva. Procedimentos de ancoragem ortodôntica. Dente impactado.

${ }^{1} \mathrm{PhD}$ student of Orthodontics and Facial Orthopedics, PUC-RS.

${ }^{2} \mathrm{PhD}$ and Professor of Orthodontics, $\mathrm{ABO} / \mathrm{RS}$.

${ }^{3} \mathrm{PhD}$ in Dentistry, ULBRA.

${ }^{4} \mathrm{PhD}$ in Oral and Maxillofacial Surgery and Professor at Graduation and Postgraduation courses, PUCRS.

" The author reports no commercial, proprietary or financial interest in the products or companies described in this article.
How to cite this article: Allgayer S, Platcheck D, Vargas IA, Loro RCD. Miniimplants: Mechanical resource for molars uprighting. Dental Press J Orthod. 2013 Jan-Feb; 18(1):134-42.

Submitted: March 16, 2011 - Revised and accepted: August 31, 2011.

" Patients displayed in this article previously approved the use of their facial and intraoral photographs.

Contact address: Susiane Allgayer

PUCRS - Pontifícia Universidade Católica do Rio Grande do Sul

Av. Ipiranga, 6681 - Prédio 06 - Sala 209

CEP: 90619-900 - Porto Alegre / RS, Brazil

E-mail: susianeallgayer@gmail.com 


\section{INTRODUCTION}

Tooth impaction is a condition in which the eruption of a tooth is interrupted as a consequence of its contact with other tooth or teeth. ${ }^{1}$ A tooth is considered impacted when, after completion of root formation, the tooth does not erupt in up to six months compared to the contralateral tooth. ${ }^{2}$

The prevalence of impaction of mandibular second molars is relatively low, nearly 1 to 3 teeth in 1,000. . $^{3,5,6}$ The most probable causes of impaction of second molars seem to be related to the excessive size of these teeth, deficient mandibular growth, inadequate length of the mandibular arch or only due to an abnormal eruption pathway. ${ }^{7,8}$

The treatment options may involve or not surgery for exposure of the molar crown and utilization of fixed and/or removable appliances. ${ }^{7-10}$

The utilization of temporary implants for orthodontic anchorage allowed a new perspective in the orthodontic treatment, especially in the permanent dentition. Mini-implants, palatal implants and mini-plates are currently used in several clinical situations, as the treatment of open bites and uprighting of molars without adverse effects on the adjacent teeth. ${ }^{11-18}$

Class II is the severe malocclusion most frequently found and is characterized by "distal positioning" of the mandibular teeth compared to the maxillary teeth, which may be caused by bone dysplasia or forward positioning of the alveolar process or maxillary dental arch, or even by the combination of skeletal and dental factors. ${ }^{9}$

This case report describes the orthodontic treatment of a patient with Angle Class II malocclusion with impaction of the mandibular second molars, in which two mini-implants were used as an anchorage aid for uprighting of the teeth, which were impacted on the distal aspect of mandibular first molars.

\section{CASE REPORT}

Caucasian patient of female gender sought for initial orthodontic treatment at the age of 9 years and 5 months. The general health status was good and there was no history of severe diseases or traumas. On the clinical examination, it was observed that the patient was in the intermediate mixed dentition and presented tongue thrusting and speech disorder.
The patient exhibited symmetric face with a slightly convex profile and competent lips. The facial thirds were proportional and the smile line was normal (Fig 1). The cephalometric evaluation revealed skeletal Class II pattern with ANB of $5^{\circ}$ due to maxillary protrusion (SNA $84^{\circ}$ ) (Fig 2 and Tab 1). Considering the values of the occlusal plane angle (SN-Occlusal Plane $15^{\circ}$ ), mandibular plane (GoGnSN 28 $8^{\circ}$ and $\mathrm{Y}$ axis (Frankfurt plane-SGn $65^{\circ}$ ), the patient presented a favorable mandibular growth pattern in both horizontal and vertical directions. Concerning the dental relationships, the maxillary and mandibular incisors were slightly buccally tipped and

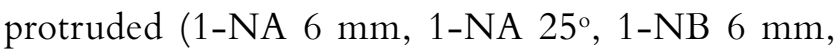
$1-\mathrm{NB} 25^{\circ}$, and IMPA $\left.95^{\circ}\right)$. The patient presented overjet of $3.5 \mathrm{~mm}$, anterior open bite, negative tooth size discrepancy of $4 \mathrm{~mm}$ in the maxillary arch and

\begin{tabular}{|c|c|c|c|}
\hline Measure & Initial & Follow-up & Final \\
\hline SNA & 84 & 82 & 81 \\
\hline SNB & 79 & 77 & 77 \\
\hline ANB & 5 & 5 & 4 \\
\hline $1-N A$ & 6 & 5 & 7 \\
\hline 1.NA & 25 & 22 & 25 \\
\hline $1-N B$ & 6 & 7 & 9 \\
\hline 1.NB & 26 & 31 & 35 \\
\hline 1.1 & 125 & 122 & 106 \\
\hline SN.Occlusal plane & 15 & 17 & 15 \\
\hline GoGn.SN & 28 & 31 & 32 \\
\hline S-UI & 2 & 1 & -1 \\
\hline $\mathrm{S}-\mathrm{LI}$ & 3 & 3 & 1 \\
\hline Y-axis & 65 & 58 & 60 \\
\hline Facial angle & 80 & 87 & 87 \\
\hline Convexity angle & 8 & 9 & 5 \\
\hline Witts & -2 & 1 & 2 \\
\hline FMA & 30 & 26 & 28 \\
\hline FMIA & 55 & 54 & 50 \\
\hline IMPA & 95 & 100 & 102 \\
\hline Nasolabial angle & 95 & 109 & 105 \\
\hline A-NPerp & -4 & -2 & -1 \\
\hline Co-A & 88 & 91 & 87 \\
\hline Co-Gn & 106 & 110 & 114 \\
\hline$M x-M n$ difference & 18 & 19 & 27 \\
\hline AFAl & 65 & 66 & 73 \\
\hline Facial axis & 0 & -4 & -5 \\
\hline Pog-NPerp & -14 & -12 & -7 \\
\hline
\end{tabular}



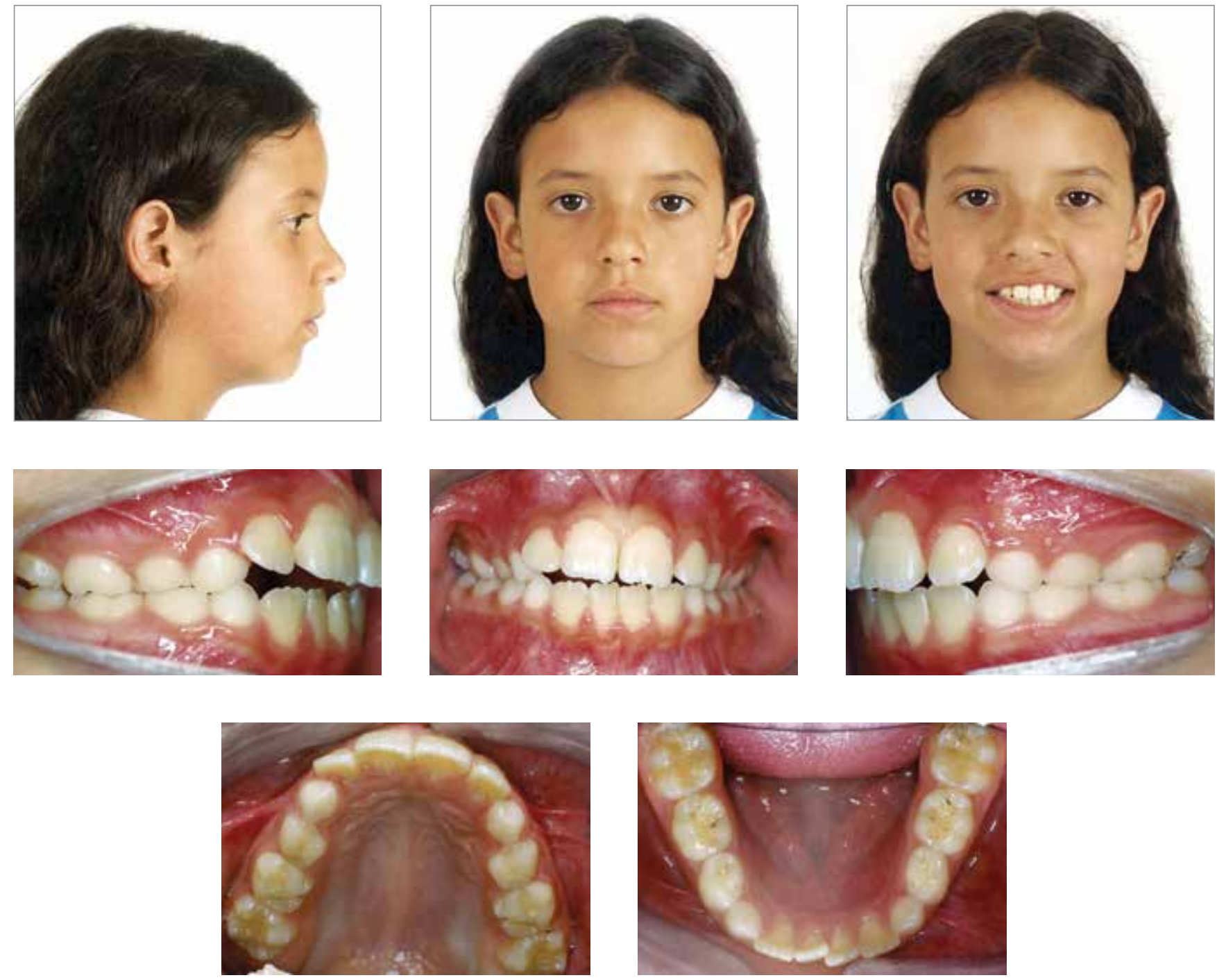

Figure 1 - Pretreatment facial and intraoral photographs.
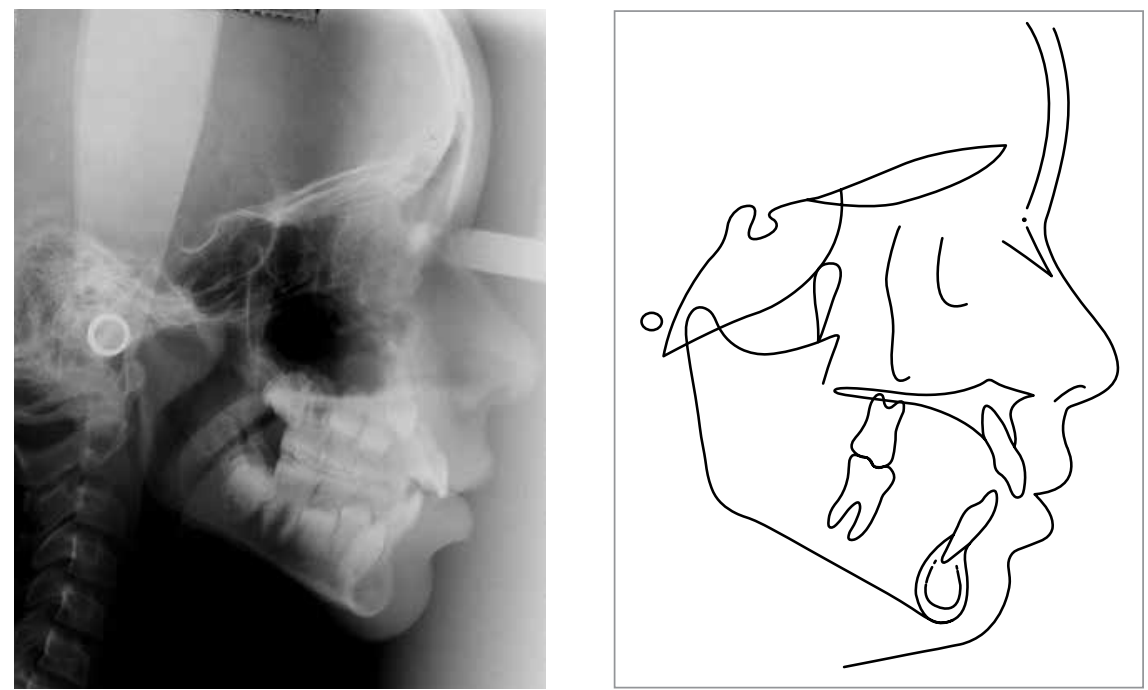

Figure 2 - Initial lateral cephalometric radiograph and tracing. 
$2 \mathrm{~mm}$ in the mandibular arch, with mild crowding in both arches. Analysis of panoramic (Fig 3) and periapical radiographs revealed the presence of all permanent teeth, including the third molars, besides deciduous canines and molars still present in the oral cavity. The hand-wrist radiograph revealed that the patient was not in the pubertal growth spurt yet.

\section{TREATMENT OBJECTIVES}

The treatment objectives were to correct the skeletal and dental Class II malocclusion and intercept the malocclusion, providing conditions for adequate growth of the bone bases, thus improving the dentoalveolar morphology. Therefore, it was necessary to control the maxillary protrusion by redirecting growth, to eliminate oral habits, to re-establish normal lip and tongue functions to correct the overbite, and to control the eruption of mandibular second molars, which presented a mesial eruption pathway.

\section{TREATMENT PROGRESS}

Initially, a maxillary appliance with tongue crib was used for six months, for tongue reeducation. After achievement of adequate overbite (Fig 3), correction of the skeletal discrepancy was initiated by redirecting maxillary growth with an extraoral traction appliance, during 10 months (Fig 5).

The fixed orthodontic appliance was placed using standard edgewise brackets, and the alignment and leveling stage was initiated.

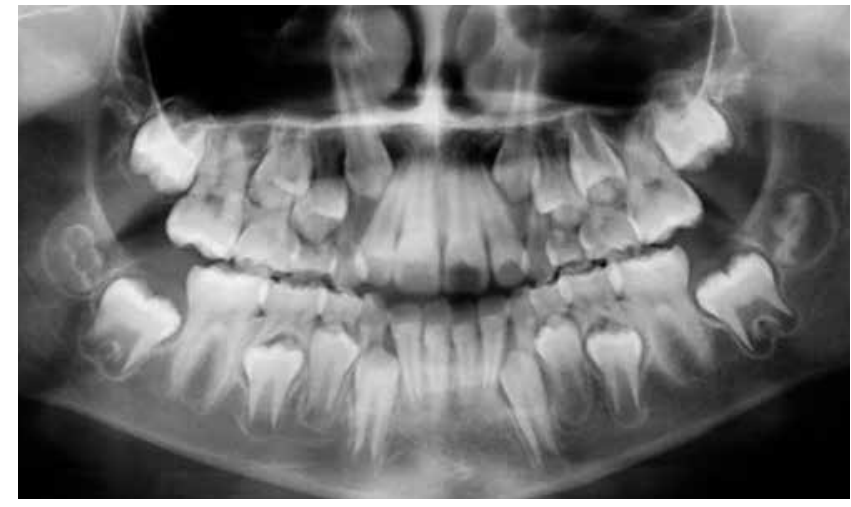

Figure 3 - Initial panoramic radiograph.

During the eruption process, the mandibular second molars presented a marked mesial eruption pathway (Fig 6), leading to impaction on the first molars. Surgical removal of third molars was indicated to enhance the uprighting of second molars. The same procedure comprised surgical exposure and bonding of a bracket on the cusp of these teeth and placement of mini-implants (Ortoimplante Conexão, 2.0 x 9.0, medium transmucous profile) for anchorage on the retromolar region, distal and occlusal to the second molars, using a mucoperiosteal flap ${ }^{11}$. This site was selected to allow support for orthodontic eruption of the impacted second molars in distal and occlusal direction (Fig 7A).
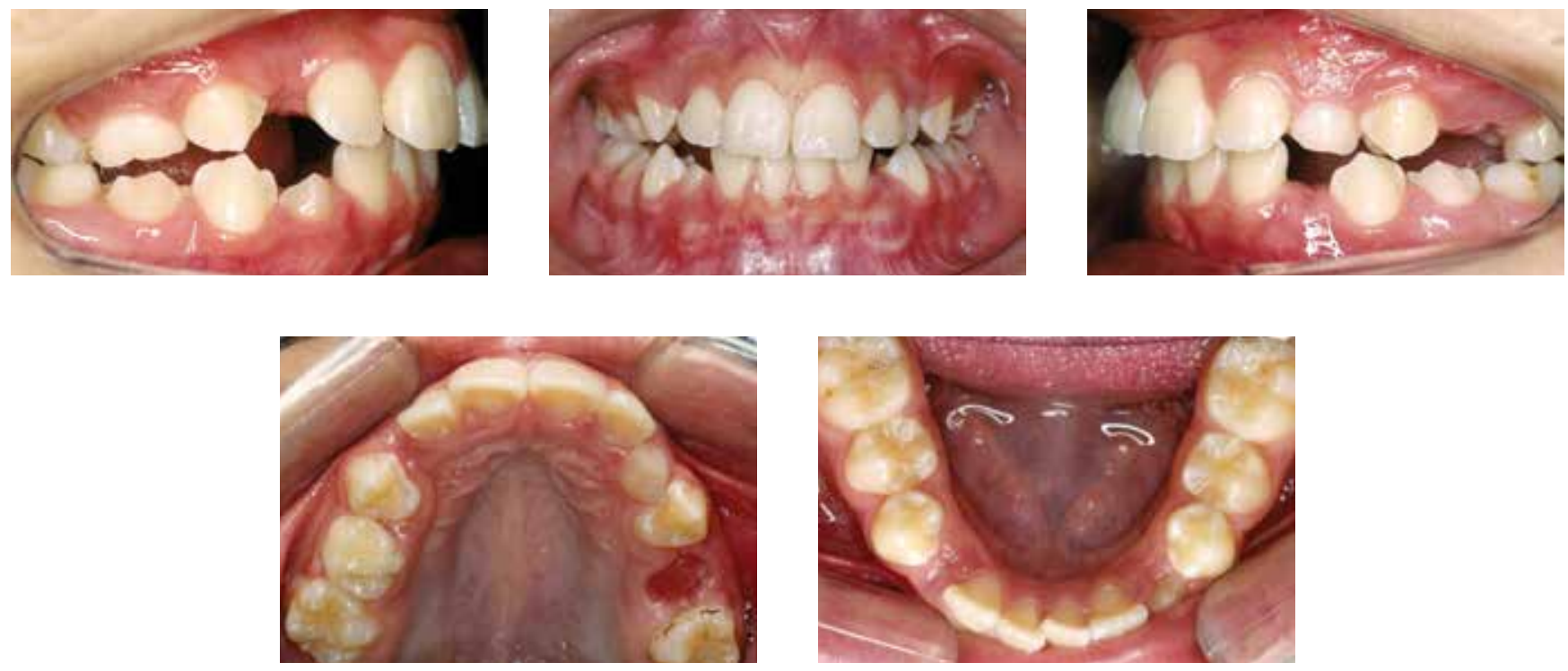

Figure 4 - Intermediate intraoral photographs. 

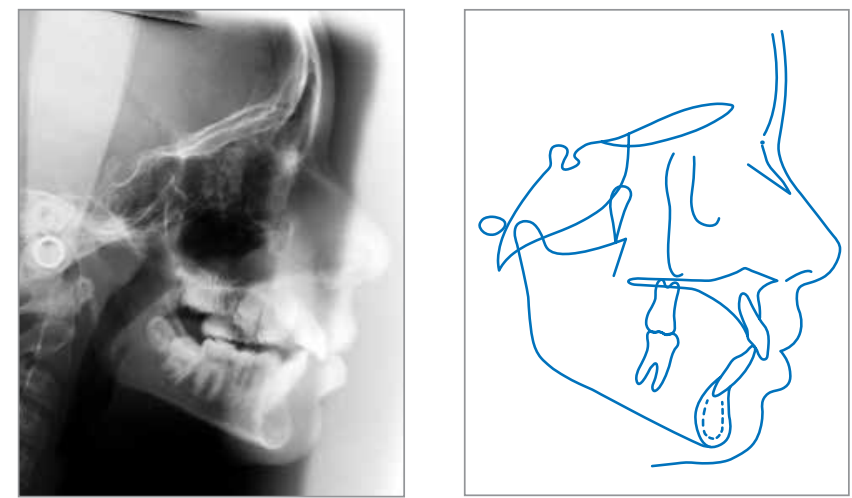

Figure 5 - Intermediate lateral cephalometric radiograph and tracing.

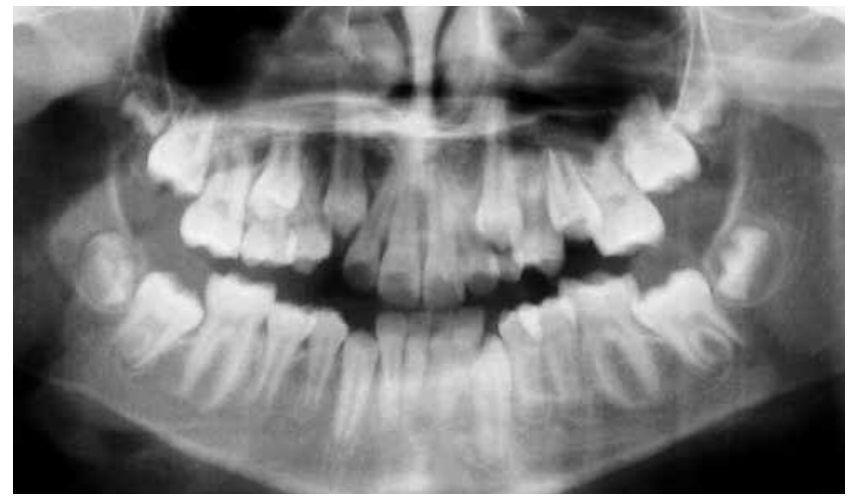

Figure 6 - Intermediate panoramic radiograph.
The affected teeth were gradually moved using chain elastics, improving their positioning (Fig 7B). The period required for uprighting was 18 months. The mini-implants did not present mobility and the patient hygiene was excellent.

The maxillary second molars did not erupt (Fig 7B). After surgical removal of fibrosis, they erupted with palatal tipping and the mandibular second molars were in buccoversion, which caused a crossbite that was treated by placement of a contracted lingual archwire, besides expansion of the maxillary arch. Simple cross vertical elastics were also used on brackets bonded on the palatal aspects of maxillary right and left second molars and buccal aspect of the mandibular right and left second molars. After 18
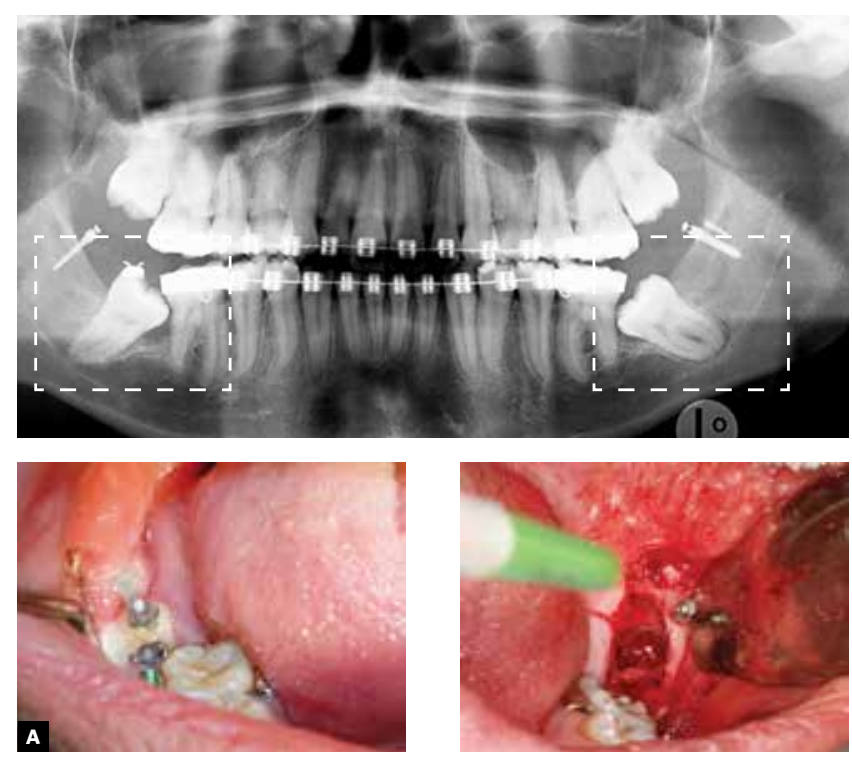

Figure 7A - Intermediate radiograph and photographs. months, they presented good inclination in the bone base (Fig 7C), were included in the archwire, the lingual arch and mini-implants were removed and corrective fixed appliances were placed for treatment finalization. There was resorption of the distal root of the mandibular right first molar, which was followed up radiographically (Figs $7 \mathrm{C}$ and $\mathrm{D}$ ).

The total treatment time with the fixed appliances was eight years, due to the period elapsed to wait for eruption of the maxillary and mandibular second molars. After orthodontic finishing and improvement of occlusion, the appliance was removed and a wraparound removable orthodontic retainer was placed in the maxillary arch, as well as a mandibular $3 \times 3$ bonded lingual retainer.
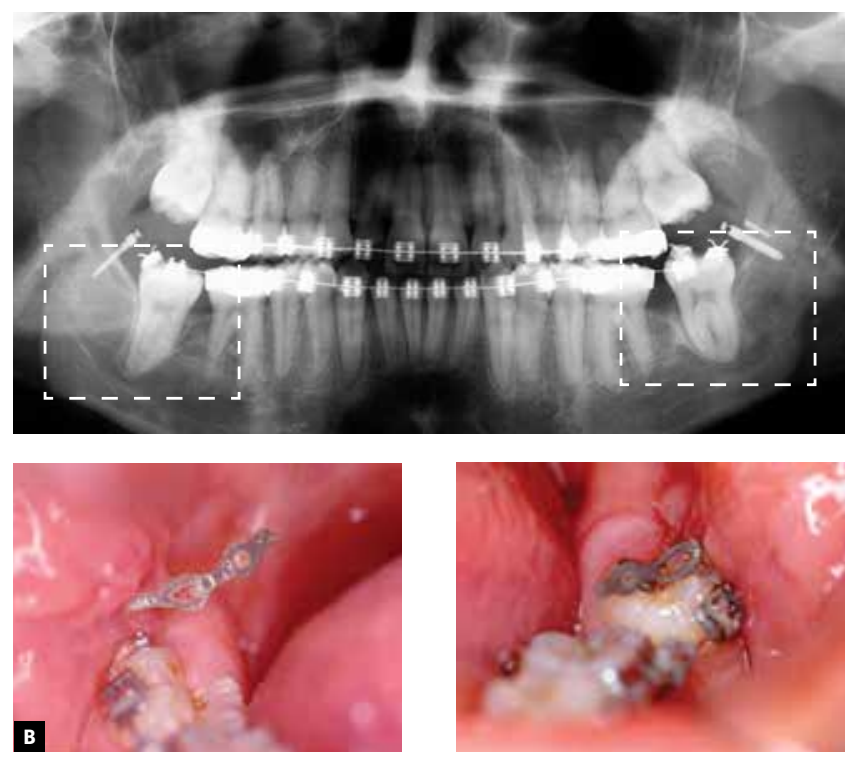

Figure 7B - Intermediate radiograph and photographs. 

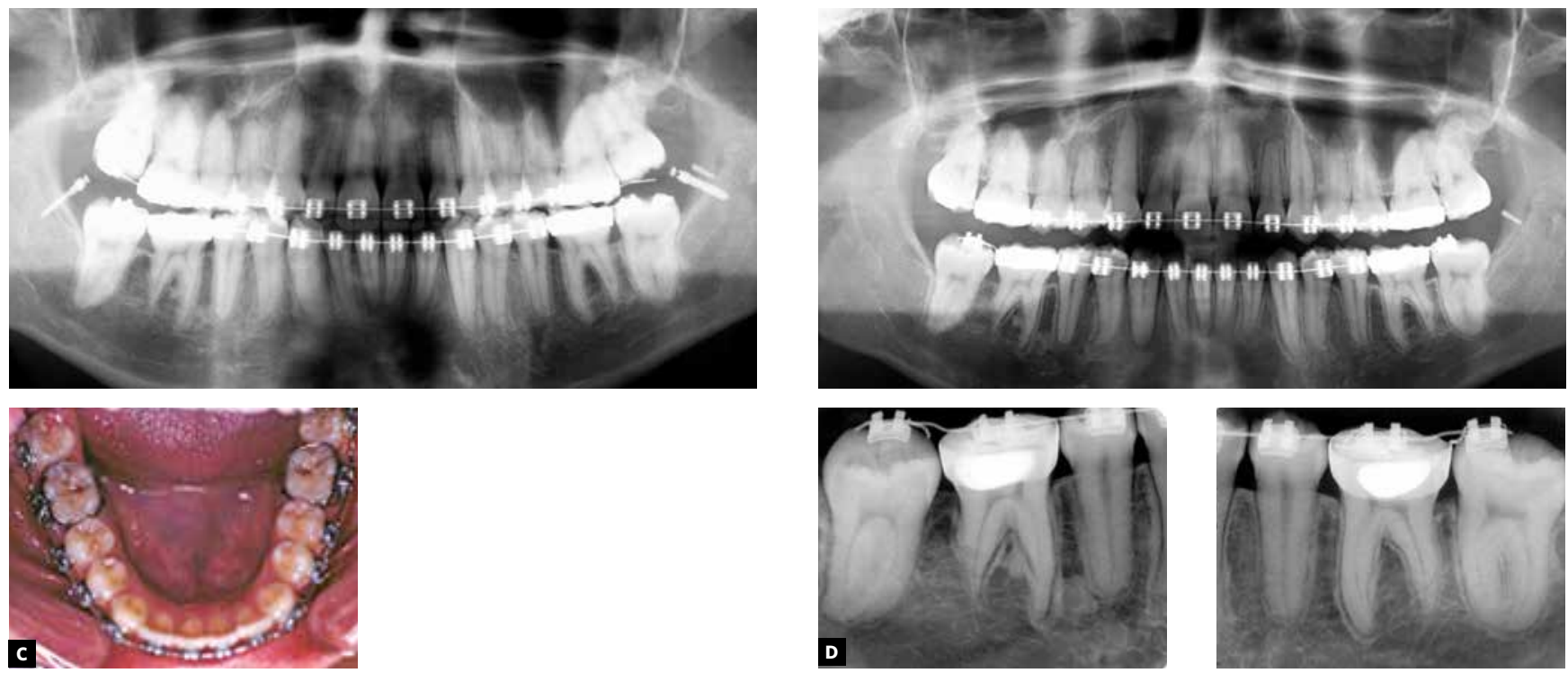

Figure 7C - Intermediate radiograph and photograph

Figure 7D - Intermediate radiographs.
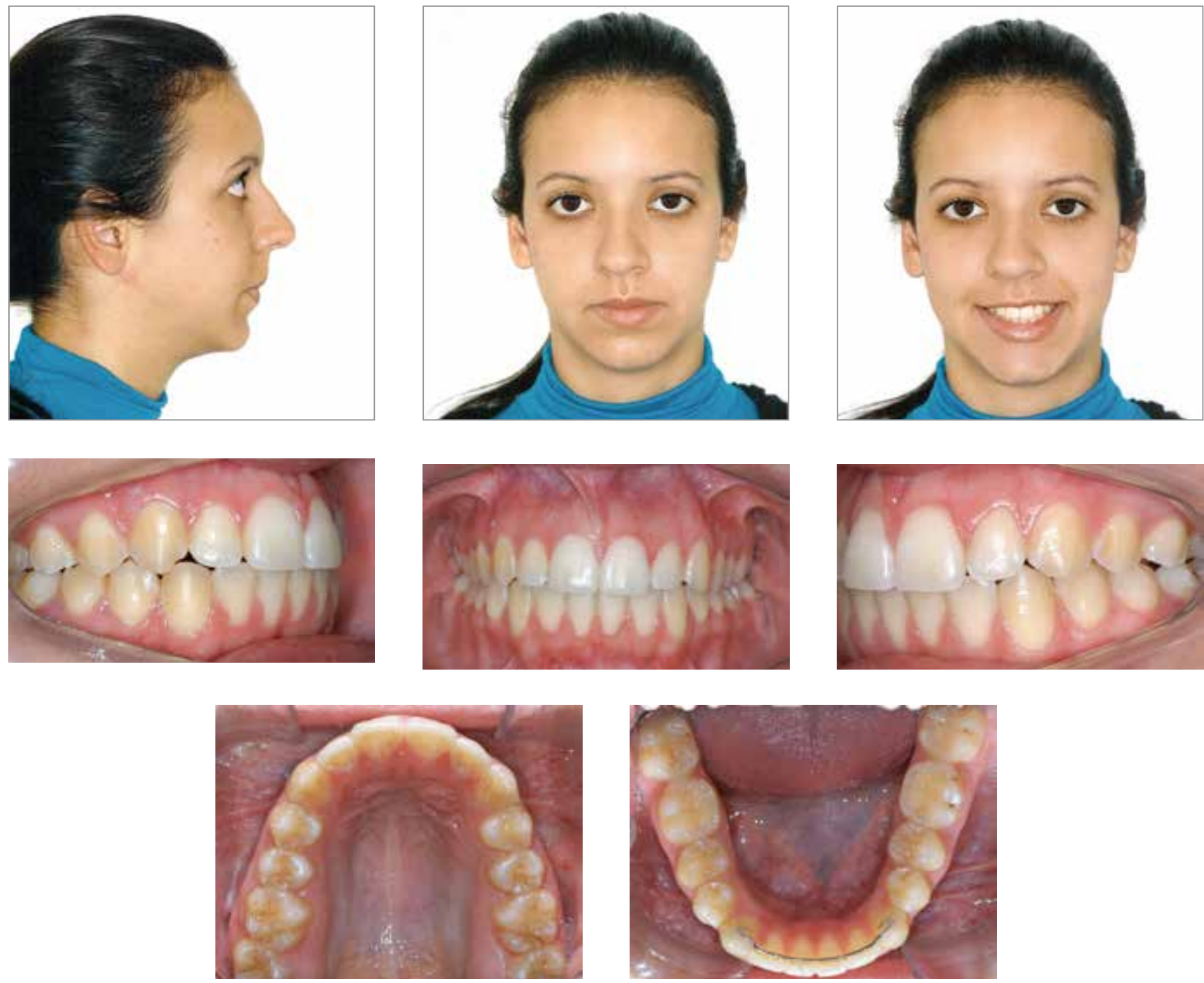

Figure 8 - Final facial and intraoral photographs. 

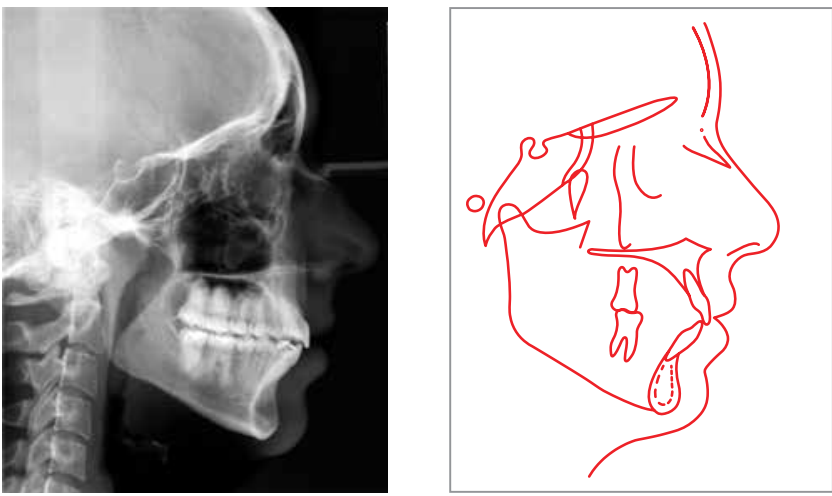

Figure 9 - Final lateral cephalometric radiograph and tracing.

\section{TREATMENT RESULTS}

At treatment completion, the facial outcome was excellent. The intraoral analysis revealed Class I molar and canine relationship, adequate overjet and overbite, coincident midlines and adequate intercuspation between the dental arches, including the second molars. The panoramic radiograph evidenced correct parallelism between the roots, and the cephalometric tracing and superimposition on the cephalogram revealed the dental and skeletal changes achieved at treatment completion (Figs 8 - 11, Tab 1).

\section{DISCUSSION}

Tooth impaction may be caused by factors as heredity, malposition of the tooth germ, overretention of deciduous teeth, localized pathological lesions, reduced arch length and deficient growth of the mandibular ramus. ${ }^{9}$ The mandibular second molars may be impacted or severely malpositioned and are often blocked under the distal convexity of permanent first molars. Their early repositioning is usually advantageous during active root development. ${ }^{9,10,19}$

The utilization of mini-plates was initially suggested as orthodontic anchorage for distal movement of mandibular molars, which was necessary in cases like this. The placement and removal require invasive surgery, which may lead to infection. ${ }^{13,18}$ The utilization of endosseous implants as anchorage in retromolar, ${ }^{21,22}$ palatal and edentulous areas has been successfully described in the literature, ${ }^{11,16,23,24}$ however they require osseointegration before the orthodontic force is applied, thus increasing the treatment time, besides the limited sites for placement.

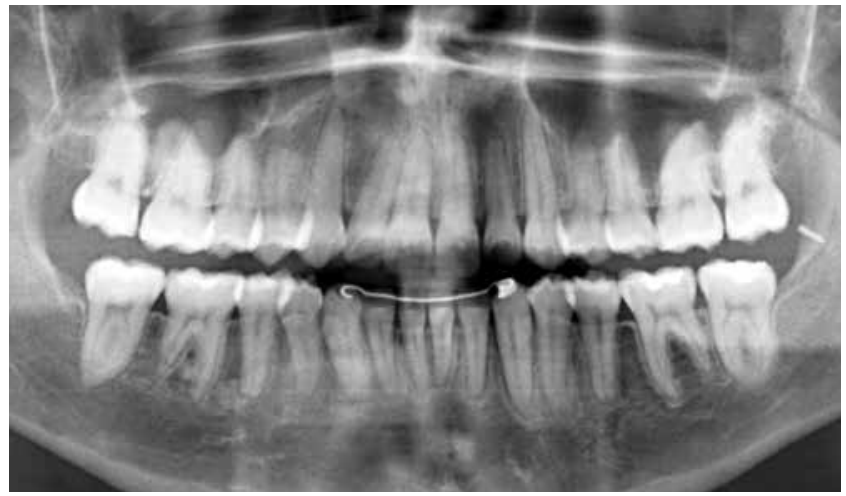

Figure 10 - Final panoramic radiograph.

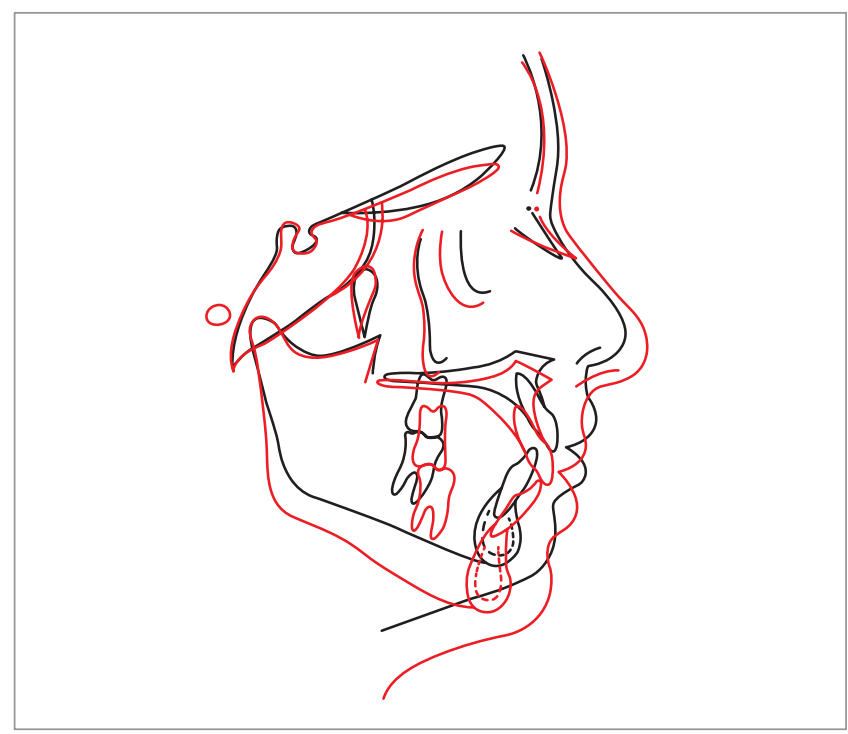

Figure 11 - Superimposition of cephalometric tracings at pretreatment (black) and posttreatment (red), with parallel Sella-Nasion lines and register at Sella for growth analysis. The redirection of maxillary growth combined to the favorable mandibular horizontal growth corrected the malocclusion.

Both mini-plates and endosseous implants are costly and difficult to be removed. ${ }^{13,18,25}$

However, skeletal anchorage has surely been an important tool in Orthodontics. These treatments require minimum patient compliance and a good oral hygiene can be more easily maintained. Even in patients who do not need prosthetic rehabilitation, recent studies have used the retromolar, palatal and alveolar regions for the placement of implants only for orthodontic purposes, for induced movement of teeth or segments. ${ }^{16}$ 
Different from the aforementioned resources, the mini-implants are easy to insert and remove, may be used immediately, are less costly and may be placed in several sites, increasing their versatility. ${ }^{12,15,25}$ The anchorage using mini-implants is as effective as the aforementioned mechanisms and has the advantages of being minimally invasive, the insertion technique is simple and facilitates the surgical procedure, providing reduced surgical time. ${ }^{16}$ For these reasons, in several clinical situations, they are preferred as a skeletal anchorage method ${ }^{25}$.

The site for fixation of the orthodontic miniimplant should present sufficient quantity of cortical bone tissue to assure immediate mechanical stability, minimum discomfort to the patient, safety to anatomical structures, as well as to allow the application of adequate biomechanics. The retromolar region ${ }^{21,22}$ is indicated to promote the uprighting of molars because it increases the distal force component. When mini-implants are placed at this region, it is also possible to achieve extrusion forces with a distal component, another reason for selecting this treatment. ${ }^{26}$

One of the goals of orthodontic treatment is to achieve a harmonious arch shape. Transverse problems should be corrected soon after diagnosis to prevent bone deficiencies. ${ }^{27}$ When a tooth presents crossbite, it rarely presents alterations only in its axial inclination. The opposing tooth in the other arch is often also malpositioned. Thus, the mandibular tooth may be in buccoversion and the maxillary tooth in palatoversion. In these cases, both should be corrected and simple cross elastics are indicated. In the present case, brackets bonded on the surfaces of molars were used to position the elastics to correct the crossbite. The technique is relatively easy, but requires patient compliance. ${ }^{28}$ Combined to elastics, a contracted lingual archwire soldered to the bands on the mandibular right and left second molars was placed, because they presented with marked buccoversion.

Similar to the aforementioned problem, deleterious habits should be interrupted as early as possible, to reestablish the normal lip and tongue functions in order to allow a correct overbite. In the present case, a maxillary removable appliance fabricated with clear acrylic and a tongue crib fabricated with $0.7 \mathrm{~mm}$ stainless steel wire was used for tongue reeducation. This appliance - which is easy to be made and is fixed in the oral cavity using Adams clasps in the molars and Kennedy clasps in the canines - intercepted the local factors that precluded tooth eruption in their normal position and allowed stable outcomes during treatment.

External root resorption is a common complication of orthodontic treatment. The esthetic and function improvement often compensate the treatment risks. ${ }^{29}$ Reduction of the root length does not reduce the longevity or functional capacity of the affected teeth; after the force is removed, there is the repair process and reestablishment of the periodontal ligament. ${ }^{30}$ In the present case, resorption of the mandibular right first molar observed during treatment was controlled by radiographic follow-up and force control. Considering the large movement of the second molar, repair of the periodontal ligament of the mandibular right first molar and reestablishment of the normal functions of the two teeth, resorption of the first molar was clinically acceptable (Figs 7C and D).

Ultimately, the mini-implants provide biomechanical advantages that allow an easier and more effective treatment, without the need of patient compliance. ${ }^{17,26}$ The preference of clinicians for a certain treatment modality must not be necessarily followed. After deciding that the utilization of mini-implants is safe and necessary for the treatment, the area of insertion should be selected considering the accessibility, conditions of soft and hard tissues, biomechanical utility in orthodontics, comfort to the patient and possibility of irritation of the adjacent oral tissues. ${ }^{26}$

\section{CONCLUSION}

Disimpaction of the mandibular second molar, comprising extraction of the third molar, exposure of the crown of the impacted tooth for bonding of orthodontic bracket followed by orthodontic mechanics demonstrated to be a safe and effective approach with minimum discomfort to the patient. The mechanics required only two mini-implants placed at the retromolar region, which allowed correct positioning of the second molars impacted in the dental arch. Good results were obtained and the orthodontic treatment objectives were achieved; also, the Class II molar relationship and open bite were corrected, thus yielding an occlusion with excellent function and esthetics. 


\section{REFERENCES}

1. Hitchin AD, Durh MDS, Edin RCS. The impacted maxillary canine. Br Dent J. 1956:100(1):1-14.

2. Lindauer SJ, Rubenstein LK. Canine impaction identified early with panoramic radiographs. J Am Dent Assoc. 1992;123(3):91-7.

3. Grover PS, Lorton L. The incidence of unerupted permanent teeth and related clinical cases.Oral Surg Oral Med Oral Pathol. 1985:59(4):420-5.

4. Varpio M, Wellfelt B. Disturbed eruption of the lower second molar: clinical appearance, prevalence, and etiology. ASDC J Dent Child 1988:55(2):114-8.

5. Montelius GA. Impacted teeth: a comparative study of chinese and canadian dentitions. J Dent Res. 1932;12(6):931-8.

6. Johnsen DC. Prevalence of delayed eruption of permanent teeth as a result of local factors. J Am Dent Assoc. 1977;94(1):100-6

7. Lima CEO, Henriques JFC, Janson GRP, Freitas MR. Segundo molar inferior impactado: revisão e apresentação de um caso clínico. Rev Clín Orthod Dental Press. 2004:2(6):68-75.

8. Teixeira RG, Vidal BC, Bastos EPS. Reposicionamento cirúrgico de um segundo molar inferior direito impactado com cárie: relato de caso. J Bras Ortodon Ortop Facial. 2000:5(30):76-81

9. Moyers RE. Ortodontia. 4a ed. Rio de Janeiro: Guanabara Koogan; 1991

10. Pogrel MA. The surgical uprighting of mandibular second molars. Am J Orthod Dentofacial Orthop. 1995:108(2):180-3

11. Faber J, Velasque F. Titanium miniplate as anchorage to close a premolar space by means of mesial movement of the maxillary molars. Am J Orthod Dentofacial Orthop. 2009;136(4):587-95

12. Cope JB. Temporary anchorage devices in orthodontics: a paradigm shift. Semin Orthod. 2005:11(1):3-9

13. Faber J, Morum TFA, Leal S, Berto PM, Carvalho CKS. Miniplacas permitem tratamento eficiente e eficaz da mordida aberta anterior. Rev Dental Press Ortod Ortop Facial. 2008:13(5):144-57

14. Faber J. Ancoragem esquelética com miniplacas. In: Lima Filho RMA Bolognese AM. Ortodontia: arte e ciência. Maringá: Dental Press; 2007. p. 449-73

15. Kuroda S, Katayama A, Takano-Yamamoto T. Severe anterior openbite case treated using titanium screw anchorage. Angle Orthod. 2004;74(4):558-67.

16. Erverdi N, Keles A, Nanda R. The use of skeletal anchorage in open bite treatment: a cephalometric evaluation. Angle Orthod. 2004;74(3):381-90.
17. Sugawara J, Kanzaki R, Takahashi I, Nagasaka H, Nanda R. Distal movement of maxillary molars in nongrowing patients with the skeletal anchorage system. Am J Orthod Dentofacial Orthop. 2006:129(6):723-33.

18. Sugawara J, Daimaruya T, Umemori M, Nagasaka H, Takahashi I, Kawamura H, et al. Distal movement of mandibular molars in adult patients with skeletal anchorage system. Am J Orthod Dentofacial Orthop. 2004;125(2):130-8

19. Vedtofte $H$, Andreasen JO, Kjaer I. Arrested eruption of the permanent lower second molar. Eur J Orthod. 1999:21(1):31-40.

20. Rindler A. Effects on lower third molars after extraction of second molars. Angle Orthod. 1977:47(1):55-8.

21. Higuchi KW, Slack JM. The use of titanium fixtures for intraoral anchorage to facilitate orthodontic tooth movement. Int J Oral Maxillofac Implants. 1991;6(3):338-44

22. Roberts WE, Marshal KJ, Mozsary PG. Rigid endosseous implant utilized as anchorage to protract molars and close an atrophic extraction site. Angle Orthod. 1990;60(2):135-52

23. Lee JS, Kim DH, Park YC, Kyung SH, Kim Tk, The efficient use of midpalatal miniscrew implants. Angle Othod. 2004;74(5):711-4.

24. Wehrbein H, Merz BR, Diedrich P, Glatzmaier J. The use of palatal implants for orthodontic anchorage. Design and clinical application of the orthosystem. Clin Oral Implants Res. 1996:7(4):410-6.

25. Joseph S. Petrey, Marnie M. Saunders, G. Thomas Kluemper, Larry L. Cunningham, and Cynthia S. Beeman. Temporary anchorage device insertion variables: effects on retention. Angle Orthod. 2010;80(4):63441.

26. Lee JS, Kim DH, Park YC, Vanardall RL. Aplicação dos mini-implantes ortodônticos. São Paulo: Quintessence; 2009.

27. Joondeph DR. Mysteries of asymmetries. Am J Orthod Dentofacial Orthop. 2000;117(5):577-9

28. Assed S. Odontopediatria: bases científicas para a prática clínica. São Paulo: Artes Médicas; 2005

29. Tanaka OM, Amorin LH, Shintcovsk RL, Hirata TM. Treatment of patient with severaly shortened maxillary central incisor roots. J Clin Orthod 2008:42(12):729-31.

30. Ramanathan C, Hofman Z. Root resorption in relation to orthodontic tooth movement. Acta Medica (Hradec Kralove). 2006;49(2):91-5. 